the second and fourth and half an inch longer than the first. Tail with fourteen feathers.

\title{
Measurements in inches.
}

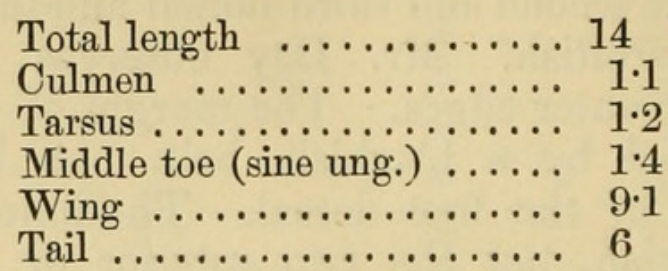

"q. Mantanani. Iris crimson; bill light-lead grey; feet dull crimson. 17th Dec., 1887." $-A$. H. E.

\section{Treron nasica, Schl.}

Two specimens of this bird were obtained by Mr. Everett at Banguey, off the north coast of Borneo. One is a fully adult bird, and the other probably a somewhat immature female; but unfortunately no particulars are given on the collector's labels except the locality. This species may be easily distinguished from the nearly allied forms T. nipalensis, Hodgs., and T. griseicauda, G. R. Gr., not only by its smaller size, but by the difference in the colour of the lesser wing-coverts. The various differences may be tabulated as follows :-

Lesser wing-coverts pale grey. Cheeks green. Head darker grey on the top. Mantle uniform dull green.

W. 5.3 in ............................. Tasica.

Lesser wing-coverts dark blackish grey. Cheeks grey. Head uniform light grey, like cheeks. Sides of mantle washed with buffy orange. W. $6 \cdot 1$ in. ... T. griseicauda.

Lesser wing-coverts dull vinous red, same as back.

Cheeks green. Head darker grey on the top.

Mantle uniform greyish green. W. $5 \cdot 6$ in........ T. nipalensis.

\section{MISCELLANEOUS.}

Remarks on a Note by Dr. G. Baur on the Pleurodiran Chelonians.

By G. A. Boudenger.

A RECENT number of the 'Zoologischer Anzeiger' (no. 285, 6th August, 1888) contains a note by Dr. Baur in which he contradicts 
me as to the existence of some of the characters which I have indicated as diagnostic of the Pleurodiran Chelonians.

First, my statement that "The mandible articulates with the skull by a condyle fitting into a concavity of the quadrate" is followed by the remark that "Dasselbe ist der Fall bei den Chelydridæ und Cinosternidæ und anderen." This is evidently due to my critic not having understood my meaning; but it shows how very superficial a knowledge he must have of the Chelonian skulls not to have noticed the great difference in the articulatory region of the mandible of a Pleurodiran as compared with any other Chelonian. Secondly, my statement that "The outer border of the tympanic cavity is completely encircled by the quadrate" is contradicted thus :- "Dies ist nicht volkommen der Fall bei Chelymys victorice, während dieselbe Eigenschaft auch den Chelydridæ und Trionychidæ zukommt." Here, again, Dr. Baur misunderstands me ; had he referred to the publication he quotes he would have found that I do not include the Trionychidæ either among the Cryptodira or among the Pleurodira; and had he taken the trouble of comparing a skull of a Chelydroid with that of a Chelydoid he would have seen that in the latter the ear-chambers are closed posteriorly precisely where they are open in the former, and vice versa .

I think it desirable to make this reply, because the accuracy of my statements is called into question in a most offhand manner by a zoologist who evidently writes on these matters without specimens before him : and I seize this opportunity for expressing an opinion on that author's recent publications on the Chelonia.

His views as to the relationships of the Sphargidæ, which have, in his own writings, already undergone various modifications *, have been most ably refuted by Dollo, whose criticisms have not yet been answered. For my part, I have to say that the statement that Dermochelys differs from the Chelonidæ only in the configuration and isolation of the carapace is simply monstrous, and that Dr. Baur could not have been acquainted with Dermochelys at the time he published his note. What! he actually states that the head and limbs are fundamentally the same in Dermochelys and in the Chelonidæ! The skull of the former bears a general resemblance to that of the true turtles; but this is limited to the shape and, to a certain extent, the general constitution of the temporal roof ; in the absence of the column-like processes of the parietals, descending to the pterygoids in front of the supraoccipital and the prootics, it differs from that of all other Chelonians. As to the limbs, in spite of adaptive similarity, they differ in most important points. Thus, in addition to the shape of the humerus and the proportions of the phalanges, the fore limb differs in the radius and ulna being subequal in length and placed side by side in a horizontal plane, and in the fifth metacarpal, instead of the first, being the shortest.

The mosaic-like dorsal plates of Eretmochelys are now admitted

* Cf. Zool. Anz. 1886, p. 687; Amer. Nat. 1887, p. 89; Zool. Anz. 1888, p. 423. 
by Dr. Baur himself not to be constant; and I presume it will ultimately be found that his observation was made on an injured specimen.

In his latest paper on the classification of the Pleurodira Dr. Baur gives as one of the characters of the family Chelydidæ the presence of a nuchal shield, and includes Elseya, overlooking that that genus was established on the absence of a nuchal.

So much for Dr. Baur's accuracy in dealing with facts. His want of judgment as to what constitute family characters is best shown in his classification of the Pleurodira, where one neural plate more or less (often merely an individual peculiarity) is regarded as a family character, except in the Chelydidæ, where, better informed, he admits their variation from 7 to 0! Pelomedusa, which is placed by him with Podocnemis in the family Pelomedusidæ, is beyond question much more nearly related to Sternothcerus, which, in his system, forms another family. As there is not at present the slightest reason for splitting the Pelomedusidæ, or Pleurodira with mesoplastra, into several families, the new terms Mesoplastralia and Amesoplastralia were uncalled for, and only show, together with the proposal of a new name (Erymnochelys) to replace Dumeritia, preoccupied and a synonym of Podocnemis, the unfortunate fondness of the author for coining names whenever the slightest opportunity offers.

A Comparison of the Cretaceous Fish-fauna of Mount Lebanon with that of the English Chall**. By A. SмIтH Woodward, F.G.S., F.Z.S.

No detailed comparison having hitherto been instituted between the Cretaceous fish-fauna of Mount Lebanon and that of the English Chalk, which belongs to a well-determined horizon, the author has undertaken a general survey of the genera, with the result that the two faunas are proved to have more forms in common than hitherto supposed. The Selachian fishes are scarcely comparable, Notidanus and Squatina being the only genera as yet recognized in the two formations, although the English teeth named Lamna rhaphiodon seem to belong to the Syrian shark named Rhinognathus; on the whole, those of Mount Lebanon exhibit the most modern facies, all traces of Hybodont Sharks and of Ptychodus being wanting. Chimæroids are unknown at Mount Lebanon, but abundantly met with in the English Chalk. Among Ganoids there are representatives of the Pycnodonts both in the Lebanon (Palceobalistum, Coccodus, Xenophotis) and in England (Coelodus), but no identical genera can yet be recognized. Rhombic-scaled Ganoids are rare in the English Chalk (Lophiostomus, Neorhombolepis), and unknown in Mount Lebanon; traces of Acipenseroids also occur in the former, but have not been discovered in the latter; and at least one Crossopterygian genus occurs plentifully in England (Macropo-

* Abstract of paper read before Section C, British Association, Bath, September 1888. 


\section{$2 \mathrm{BHL}$ Biodiversity Heritage Library}

Boulenger, George-Albert. 1888. "Remarks on a note by Dr. G. Baur on the Pleurodiran Chelonians." The Annals and magazine of natural history; zoology, botany, and geology 2, 352-354. https://doi.org/10.1080/00222938809460939.

View This Item Online: https://www.biodiversitylibrary.org/item/81046

DOI: https://doi.org/10.1080/00222938809460939

Permalink: https://www.biodiversitylibrary.org/partpdf/62846

\section{Holding Institution}

Smithsonian Libraries

\section{Sponsored by}

Smithsonian

\section{Copyright \& Reuse}

Copyright Status: Public domain. The BHL considers that this work is no longer under copyright protection.

This document was created from content at the Biodiversity Heritage Library, the world's largest open access digital library for biodiversity literature and archives. Visit BHL at https://www.biodiversitylibrary.org. 